\title{
PRZYCZYNEK DO BIOGRAFII KS. PIOTRA ŻYLIŃSKIEGO (1816-1887)
}

Kościół katolicki na Ziemiach Zabranych od 1798 roku posiadał sześć diecezji: metropolitalną mohylowska, wileńska, żmudzką, mińską, łucko-żytomierską i kamieniecką. Później, po 1847 roku, utworzona została jeszcze w cesarstwie rosyjskim diecezja tyraspolska. Ich dzieje były ściśle powiazzane z losami społeczeństwa i pozostawały stale w polu polityki carskiej zmierzającej do rusyfikacji ziem anektowanych na zachodnich rubieżach imperium. Skutki tej polityki były najbardziej odczuwalne po kolejnych zrywach narodowowyzwoleńczych (1794, $1831,1863)$. Po powstaniu styczniowym carat zlikwidował diecezję kamieniecka (1866), a następnie mińską (1869). W 1863 roku zesłano do Wiatki wileńskiego biskupa Adama Krasińskiego'; w 1866 ordynariusza kamienieckiego bpa A. Fijalkowskiego ${ }^{2}$ deportowano do Symferopola; trzy lata później biskup łucko-żytomierski Kasper Borowski $i^{3}$ został wywieziony do Permu na Uralu. Po tych deportacjach na Ziemiach Zabranych pozostał jedynie biskup Maciej Wołonczewski ${ }^{4}$ w diecezji żmudzkiej oraz w archidiecezji mohylewskiej rezydujący w Petersburgu biskup Maksymilian Staniewskis.

* Irena Wodzianowska - dr historii, adiunkt w katedrze Historii Europy Wschodniej Wydziału Nauk Humanistycznych KUL.

${ }^{1}$ Adam Stanisław Krasiński (1810-1891) biskup wileński w latach 1859-1882. Po powrocie z deportacji udał się do Rzynu, gdzie w 1883 roku złożył rezygnację z urzędu. Zob. P. Nitecki, Biskupi Kościola w Polsce. Stownik biograficzny, Warszawa 1992, s. 112.

${ }^{2}$ Antoni Fijałkowski (1797-1883) biskup kamieniecki w latach 1858-1872, następnie arcybiskup metropolita mohylowski. Zob.: P. Nitecki, Biskupi, s. 58.

${ }^{3}$ Kasper Borowski (1802-1885) w latach 1848-1883 biskup hucki i żytomierski, a po kasacie diecezji kamienieckiej jej administrator apostolski. Po ułaskawieniu w 1882 przeniesiony został na biskupstwo płockie. Zob.: P. Nitecki, Biskupi, s. 32-33.

${ }^{4}$ Maciej Kazimierz Wolonczewski (1799-1875) biskup żmudzki od 1850 roku. Zob. Nitecki, Biskupi, s. 228.

${ }^{5}$ Maksymilian Józef Staniewski (1795-1871) sufragan mohylowski od 1858 roku. Zob. Nitecki, Biskupi, s. 194. 
Pozbawioną ordynariusza diecezją wilcńską, z jego woli, rządził zastępczo ks. Józef Bowkiewicz (1793-1866). Po jego śmierci w maju 1866 roku kapituła wileńska powołała na stanowisko wikariusza kapitulnego ks. Aleksandra Ważyńskiego, ale ówczesny wilcński generał-gubernator K. Kaufmann (1865-1866) nie wyraził zgody na taki wybór. Tymczasem już wcześniej, z inicjatywy jego poprzednika N. Murawiowa (1863-1865), wprowadzono do kapituły prorządowych duchownych - Mamerta Herburtta, Antonicgo Niemeksze, Edwarda Tupalskiego i Piotra Żylińskiego. Poprzez ponowny wybór dokonany 29 maja 1866 powołano nowego wikariusza kapitulnego w osobie Piotra Żylińskiego. Nie są znane sposoby niewątpliwego nacisku politycznego poprzedzającego tę decyzję tak tragiczną dla dziejów Kościoła na Ziemiach Zabranych.

Kim był nowy wikariusz kapitulny de facto wyznaczony przez władze świeckie? Ks. Piotr Żyliński urodził się w 1816 roku w szlacheckiej rodzinie. Po ukończeniu instytutu szlacheckiego wstąpił do zgromadzenia księży misjonarzy w Wilnie $(1838)^{6}$. Po zniesieniu zgromadzenia w 1844 roku pozostał w Wilnie, zamieszkując u swojego szwagra. Najprawdopodobniej rok wcześniej, uzyskał święcenia kapłańskie, gdyż od 1844 pracowal już jako wikariusz parafii św. Jana w Wilnie. W 1848 roku został mianowany administratorem parafii Soły, później Radoszkowicze. W obu parafiach dał się poznać jako dzielny budowniczy: w Sołach odbudowal kościól, a w Radoszkowicach zbudował nowy na micjscu spalonego. W 1854 został wilejskim dziekanem i deputatem wilejskiego powiatu. Pod koniec powstania wrócił do Wilna jako proboszcz Ostrej Bramy (w maju 1864). Od kwietnia 1864 pracował także jako prowizor przy seminarium duchownym. W 1858 roku został mianowany kanonikiem, w 1863 na wniosek Murawiowa prałatem ${ }^{7}$. Rok wcześniej - w 1862 obronił magisterium w Petersburskiej Akademii Duchownej ${ }^{8}$.

Działalność Żylińskiego jako rządcy diecezji najpierw wileńskiej, a od 1869 także mińskiej trwała 15 lat (1866-1882). Nie mając żadnych uprawnień ze strony Stolicy A postolskiej został ekskomunikowany, zarówno za bezprawne rządy w dwu diecezjach, jak i za nieusankcjonowane kanonicznie działania w zakresie zmian liturgicznych. Znający dokładnie swoją epokę autor pisał później: „Od tej chwili hierarchiczna część Kościoła przybrała inny charakter. Obrona praw i osób kościelnych, opozycja przeciwko nastawaniu na szkodę Kościoła, wszelkie, choć mało skuteczne non possumus umilkły. Władze cywilne, osłaniać się poczęły rozporządzeniami nowego rządu diecezjalnego i konsystorza"9.

${ }^{6}$ Motiejus Valančius. Namu užrašai, sud. A. Prašmantaite, Vilnius 2003, s. 230.

${ }^{7}$ Lietuvos Valstybos Istorykas Archyvas (dalej cyt. LVIA), f. 378, g. 1863, b. 827; Российский Государственный Исторический Архив (dalej суt. РГИА), ф. 821, on. 1, д. 973; А. Ważyński, Litwa pod wzgledem prześladowania w niej rzymsko-katolickiego Kościola szczególniej w dyecezji Wileńskiej od roku 1863 do 1872, Poznań 1872, s. 33-34; Motiejus Valančius. Namu užrašai, s. 812 .

${ }^{8}$ Jak wynika z dokumentów Akademii był on jedynym z dwóch absolwentów, których egzaminy magisterskie odbyły się poza murami uczelni. PГИА, ф. 821, on. 1, д. 933; Lietuvos Mokslu Akademijos Biblioteka (dalej cyt. LMAB), f. 315, b. 1554.

${ }^{9}$ A. Ważyński, Litwa pod względem prześladowania $w$ niej rzymsko-katolickiego Kościoła, 
Ks. Żyliński czynnie współpracował z administracją carską w rusyfikacji Kościoła katolickiego ${ }^{10}$. Brał udziałał m.in. w pracach powołanej przez wspomnianego już generał-gubernatora K. Kaufmana, Komisji rewizyjnej ds. duchowieństwa katolickiego (1866-1868) ${ }^{11}$. Do jej najważniejszych zadań należało przygotowanie kasaty diccezji mińskicj, planu zamykania kościołów i kaplic, rusyfikacji liturgii i katechizacji, stworzenia nadzoru państwowego w konsystorzach i seminariach. W ramach tejże komisji utworzono specjalny wydział dla thumaczenia modlitewników, kazań, rytuału ${ }^{12}$, Ewangelii na język rosyjski'3. Przewodniczył tej pracy ks. Istkiewicz, członkami byli Ignacy Kozłowski, ks. Antoni Niemeksza i Piotr Żyliński ${ }^{14}$. Celem tej grupy było jak najszybsze wprowadzenie języka rosyjskiego do szafarstwa sakramentów świętych. Rytuał ukazał się drukiem w Wilnie w 1869 roku pod tytułem „Trebnik”. Tekst polski został całkowicie usunięty z tekstów liturgicznych i zastąpiony rosyjskim. Tekst litewski i lotewski został zapisany literami rosyjskimi ${ }^{15}$.

W diecezji wileńskiej i mińskiej administrator prałat Piotr Żyliński wydał zarządzenie, aby „Trebnik” był stosowany wszędzie, bez ograniczeń. Bezwzględna większość księży ${ }^{16}$ odmówiła swego podpisu potwierdzającego odbiór nowego rytuału. Ks. Stanisław Piotrowicz, wicedziekan wileńskiego dekanatu i proboszcz parafii św. Rafała w Wilnie, przesłane mu 143 egzemplarze „Trebnika” dla księży swojego dekanatu, spalił i wygłosił znane kazanie krytykujące postępowanie caratu i Żylińskiego, za co został zesłany przez kolejnego wileńskiego generał-gubernatora Potapowa - do guberni archangielskiej ${ }^{17}$. Po tym głośnym proteście, według późniejszych relacji gubernatorów, żaden z księży diecczji wilcńskiej nie wprowadził do kościołów katolickich „Trebnika"18. Rządca diecezji będąc milczącym świadkiem zamykania świątyń i na Wileńszczyźnie i na Mińszczyźnic, deportacji wiernych Kościołowi kapłanów, nie stanął, w obronie praw ludzi wierzących.

W 1882 roku prałat Żyliński poprosił o urlop ${ }^{19}$ pozostawiając tymczasowo

s. 39.

${ }^{10}$ Działalność Żylińskiego omawia także prof. V. Merkys w: Tautiniai santykiai Vilniaus vyskupijoje. 1798-1918, Vilnius 2006, ss. 143-144, 149, 183, 243, 266-284.

${ }^{11}$ I. Wodzianowska, Komisja Rewizyjna do spraw duchowieństwa katolickiego (1866-1868), Lublin 1997, mps.

${ }^{12}$ Rituale Sacramentorum ac aliarum Ecclesiae Romano-catholicae coeremoniarum. Ex rituali synodi provincialis Petroviensis depromtum.

${ }^{13}$ LVIA, f. 378 bs, g. 1866, b. 2522, k. 7.

${ }^{14}$ Por. S. Piotrowicz, Okólnik ks. Piotrowicza dziekana Wileńskiego, Lwów 1870, s. 35.

15 „Trebnik" miał dwa wydania: pierwsze w 1869 roku z cenzurą państwową z 1868, a drugie w 1870 roku w drukarni A. Syrkina.

${ }^{16}$ W 1872 roku na 616 kapłanów diecezji wileńskiej, podpisało się pod odbiorem rytuałów tylko 115. Ważyński, Litwa., s. 90.

${ }^{17}$ Piotrowicz, Okólnik, s. 43.

${ }^{18}$ W. Urban, Ostatni etap dziejów Kościola w Polsce przed nowym tysiqcleciem (1815-1965), Radom 1966, s. 175.

${ }^{19}$ РГИА, ф. 821 , оП. 11, д. 57 (nr 27). 
administrację kościelną w rękach prałata Klemensa Linkina ${ }^{20}$, ale tylko na krótko, gdyż w 1883 roku Stolica Apostolska mianowała ks. Karola Hryniewieckiego ${ }^{21}$ biskupem ordynariuszem diecezji wileńskiej. Prałat Piotr Żyliński wyjechał do Rzymu. Przebywając wiosną 1883 w Watykanie odbył spowiedź. Po zdjęciu ekskomuniki, a przed audiencją u papieża Leona XIII, dzięki interwencji ks. Piotra Semenenki (1814-1886), napisał list do prałata Linkina, mający być wyrazem skruchy nawróconcgo kapłana.

List ten, jak można przepuszczać, do adresata dotarl, i on sam przekazał go nie władzom kościelnym, na czym zależało Żylińskiemu i ks. Semenence, lecz świeckim. Ks. prałat Linkin należał jeżeli nie do czynnych rusyfikatorów diecezji wileńskiej, to na pewno do biernych. Jako jeden z nielicznych księży wprowadził „Trebnik" do użytku w parafii, której był proboszczem, pomimo sprzeciwu wiernych $^{22}$. Niejednokrotnie jego postawa była doceniana także przez władze carskie, które rewanżowały się honorowymi tytułami i orderami ${ }^{23}$.

Żyliński po pojednaniu się z Kościołem powrócił do Wilna, ale tu już nie pełnił żadnych ogólnodiecezjalnych funkcji. Po kilku latach -- 1887 - zmarł w Wilnie ${ }^{24}$, ale jeszcze $w$ międzyczasie ubiegał się u cara o odpowiednią emeryturę $z$ tytułu 15-letniej służby na stanowisku, do której - jak przyznaje - powołały go władze carskie. Niektóre archiwalia petersburskie utrzymuja, że cierpiał wówczas na zaburzenia psychiczne ${ }^{25}$. Zostawił po sobie pamięć tragicznej postaci, rozdartej przez lojalizm wobec zaborcy i słabość własnego charakteru. I może dlatego jeszcze w historiografii nie zgromadzono archiwaliów dotyczących tej smutnej osobistości.

Poniżej załączamy trzy różne teksty archiwalne, które w przyszłości moga być przydatne w pracy nad monografią historyczną epoki Żylińskiego i lokalnego, wilcńskiego cezaropapizmu. Teksty te pochodzą z Państwowego Archiwum Historycznego (РГИА) w Sankt-Petersburgu. Pierwszy jest protokołem z wyboru Żylińskiego na wikariusza kapitulnego, dokonanego większością głosów, w którym wzięło udział siedmiu prałatów. Wykorzystany tu rękopis został podpisany własnoręcznie przez sześciu, z wyjątkiem samego Żylińskiego, gdyż jego dotyczył. Tekst drugi jest przedrukiem odręcznego listu Żylińskiego do Linkina, z Rzymu. Tekst trzeciego dokumentu, pisany odręcznie do cara, nie pozostawia

${ }^{20}$ Klemens Linkin (1809-?) po studiach teologicznych w seminarium i Akademii uzyskał święcenia kapłańskie (1835) oraz tytuł kandydata teologii. Był m.in. administratorem w Werkach i wice dziekanem wileńskim.

${ }^{21}$ Karol Hryniewiecki (1841-1929) biskup wileński w latach 1883-1889, a po pozbawieniu go katedry był proboszczem w archidiecezji lwowskiej. Zob.: Nitecki, Biskupi, s. 82-83.

${ }^{22}$ A. Ważyński, Litwa., s. 100.

${ }^{23} \mathrm{~W}$ roku 1869 został mianowany kanonikiem, a następnie prałatem. Odznaczony m.in. orderem św. Stanisława 2 kl., LVIA, 378 bs, g. 1877, b. 331; g. 1883, b. 352.

${ }^{24}$ Pochowany na Rossie w wybudowanym na własny koszt grobowcu. E. Małachowicz, Cmentarz na Rossie w Wilnie, Wroclaw 1993, s. 303-306.

${ }^{25}$ Podobne stwierdzenie również w: J. Kurczewski, Wileńskie biskupstwo, w: Encyklopedia Kościelna, t. 31, s. 245-247. Petersburski Kraj nr 17 (1887) z dnia 12 IV 1887 pisał: „Atak nerwowy, który nawiedził go kilka lat temu, odbił sį̨ poniekąd na umyśle Żylińskiego, a w ostatnich latach odjąl mu władze w nogach”.. 
watpliwości, że ks. Żyliński ponad wszystko był lojalnym poddanym. Świadczy o tym treść listu, w którym przedstawia sam siebic jako byłcgo rządcy diecezji wileńskiej, który $w$ trudnym i odpowiedzialnym momencie stanął na jej czele. Cały kraj był wówczas ,widowiskiem buntu: świątynie katolickie były miejscem politycznych spotkań, duchowieństwo katolickie i jego hicrarchia było w centrum tych schadzek"26. Ma się wrażenie, że autor zapomniał już o swej spowiedzi. W rosyjskich dokumentach archiwalnych nie udało się odnaleźć informacji czy rząd przyznał mu odpowiednią emeryturę. Pewne jest, że już nie odegrał żadnej znaczącej roli w diecezji. W publikowanych tekstach została uwspółcześniona pisownia, natomiast nie została przeprowadzona korekta stylistyczna.

\section{Dokument $1^{27}$}

Actum in septima sessione Capituli Generalis Vernalis die 29 Maii Dominica $2^{\frac{\text { da }}{a}}$ post Pentecosten $1866^{\circ}$ Anno, prout normali celebrata praesidente Perillustri Reverendissimo Domino Praelato Scholastico etc., in praesentia Perillustrium Reverendissimorum Dominorum Praelatorum: Archidiaconi Ważyński, Custodis Niemeksza, Cantoris Kozłowski, Officialis Generalis Consistorii Żyliński, Procuratoris Capituli Tupalski et Canonici Rectoris Seminarii Zdanowicz, ac Secretarii Waszkiewicz.

Peracto solenni funere piae memoriae Illustrissimi olim ac Reverendissimi Domini Administrantis Dioecesim Praelati Praepositi Cathedrae Vilnensis S. Theologiae Doctoris, Ordinum Equitis Josephi Bowkiewicz, nudius tertius, 27ª mensis currentis: conformiter iurato Statuto, praehabito etiam ad hoc opus expresso a Superexcellenti Domino totius Lithuaniae Generali Moderatore, sub data 28 Maii, № $3.758^{\circ}$ consensu, et permissione emanatis, in Sacristia Cathedrali congregati, Iure communi ac Potestate sibi competente secretorum votorum pluralitate, Illustrissimum ac Reverendissimum Dominum Petrum Żyliński, Praelatum Aggregatum, S. Theologiae Magistrum, Consistorii Vilnensis Officialem, utpote Virum meritis praeclarum, virtutibus commendabilem atque singulari in Ecclesiasticis negotiis agendi dextcritate, nec non circumspecta prudentia pollentem, pro $\underline{\mathrm{Ad}-}$ ministratore Dioceseos, seu Vicario Capitulari temporaneo, elegerunt ac proclamarunt; omnium in hac Vilnensi Dioecesi Ecclesiarum, utriusque Cleri tam Secularis nempe quam Regularis, Ecclesiarum Regimen et inspectionem, ad interim Eidem committentes; certa spe in Domino confisi, futurum fore: ut Neo-electus Praelatus, auctus hac Dignitate, tanto magis pro communi Ecclesiae ac Dioeceseos bono, vires suas exeret, nullique parcet labori, quanto sibi hactenus apud omnes bonos fama laudabili, honore et fiducia inclaruerit. Quem suae electionis Actum canonice factum, via legali Romano Catholico Spirituali Collegio Petropolitano, pro imploranda ex parte Supremi Regiminis confirmatione quantocius remittendum constituerunt.

Praelatus Scholasticus Cathedralis Vilnensis Sanctae Theologiae Doctor Mamertus Herburtt, uti Praesidens

Praelatus Archidiaconus Alexander Ważyński

Praelatus Custos, Antonius Niemeksza

Praelatus Cantor, Simon Kozłowski

Praelatus Eduardus Tupalski

Canonicus Ludovicus Zdanowicz

26 РГИА, ф. 821, оп. 3, д. 971, k. 109 v.

${ }^{27}$ РГИА, ф. 821 , on. 3 , д. 971 , k. 3-3 v. 


\section{Dokument $2^{28}$}

\section{Le Prêlat Doyen Linkin}

\section{Szanowny Księże Kanoniku ${ }^{29}$}

Z pewnością już Ksiądz Kanonik wie dobrze o ważnych zmianach jakie po porozumieniu się rządu naszego ze Stolicą Apostolską zaszly w zarządzie Kościoła w naszych prowincjach. Ja z mej strony mam sobie za obowiązek donieść szanownemu Ks. Kanonikowi co pod czas tego ze mną się stało i prosić aby chciał o tym zawiadomić inne osoby, które mnie znają i kogo to w jakikolwiek sposób interesować może i powinno.

Wyjechawszy za granicę, prawdziwą łaską Bożą prowadzony, udałem się do Rzymu i stanąłem tu szczęśliwie. Tu dopiero poznałem jakiem byl sobie wyrobił fałszywe sumienie i jakiem nieprawnie postąpil, przyjmując naprzód wbrew prawu kościelnemu zarząd diecezji wileńskiej za życia jej prawowitego pasterza; nastçpnie zaś podobnyż zarząd diecezji mińskiej bez przyzwolenia Stolicy Apostolskiej, i narażając się przez to, a następnie popetniając cały szereg aktów nieprawnych. To poznawszy, a zarazem karę ekskomuniki, w jaką przez to popadłem, żałowałem bardzo jako dobry katolik i syn Kościoła świętego pragnący być mu wiernym, tego postępku mojego; a chcąc, ile być mogę naprawić zło, które popełnił, stanąłem dobrowolnie przed Najwyższym Trybunałem Stolicy Apostolskiej i oskarżyłem się sam ze wszystkiego, prosząc o przebaczenie. Nie mogc dosyć wypowicdzieć z jaką łaskawością i miłosierdziem byłem przyjęty przez Apostolską Stolicę, która zważając na moja prawdziwą skruche, a mogę powiedzieć i na łzy moje, niczego więcej nie wymagała, jak ścislego z mej strony powrócenia do prawa kościelnego i zachowania go odtąd jak najwierniejszego. Wyrzekłem się tedy wszystkich moich błędów, złożyłem podobnież wszystkie moje urzędy i godności nieprawnie przezemnie przyjęte; a przyrzekłszy posłuszeństwo i wierność na przyszłość, zostałem przyjęty napowrót do jedności z Kościołem, rozgrzeszony i potwierdzony w urzędach i godnościach, jakie miałem dawniej przed moim nieszczęśliwym upadkiem.

Ojciec Swięty raczył mnie łaskawie zawiadomić o swojem zadowolcniu, a zarazem, że mnie będzie widział na audiencji u siebie przed moim wyjazdem, co $w$ tych dniach nastąpi; a będzie to dla mnie największą radością ujrzeć się jako syn, chociaż marnotrawny, u stóp Ojca najlepszego.

Powtarzam szanownemu Ks. Kanonikowi, że była to prawdziwa a wiclka łaska Boża, która mnie przyprowadzila do Rzymu, że nie mogę dosyć nadziękować się Panu Bogu za nią ani opisać szczęścia mego dzisiejszego, które niezawodnie szanowny Ks. Kanonik będzie ze mną podzielał. Powtarzam i to także, że prosz̨̨ udzielać wszystkim, komu tylko będzie można, tych wiadomości o mnie, a gdyby była sposobność oświadczenia tego Najprzewielebniejszemu nowemu Pasterzowi naszej diecezji, proszę go zapewnić, że w całej diecezji nie będzie miał powolniejszego ani wierniejszego syna i sługi nademnie.

Rzym, 17 Kwietnia 1883 roku

${ }^{28}$ РГИА, ф. 821, on. 3, д. 971, k. 95-95 v., 99.

${ }^{29} \mathrm{Na}$ lewym polu napis ołowkiem: Перевод сего письма доставлен и.д. Виленского генсрал-губернатора. Tekst thumaczenia na język rosyjski - k. 96-98 v. 


\title{
Dokument $3^{30}$
}

\author{
954/254Д[епартамент]. Дух.[овных] Д.[ел] \\ от Е[го].И[мператорского].В.[еличества] 25 января 1884
}

\author{
Августейший Монарх \\ Всемилостивсйщий Государь
}

Бывшим Главным Начальником Северо-Западного Края, Графом Муравьевым, я был призван к деятельному участию в управлении Виленской римско-католической епархией, с постепенным расширепием круга моих обязанностей чрез последовательные назначения меня на должности: прелата, оффициала римско-католической консистории, наблюдателя за воспитанием и образованием юношества в католической духовной семигарии и цензора. К этому же времени относится и назначение меня, по инициативе графа Муравьева, настоятелем Остробрамского костела - этого католического сердца в крае.

Нст возможности описать всех трудностей, всех преград, какие ежеминутно ставили стороппики политических смут на пути к выполнению возлагавшихся на меня обязанностей, доверием правительства. Известно, что в то время Западный край представлял зрелище крамолы: католические храмы изображали политические сборища; католическое духовенство и высшие над ними иерархи олицстворяли представитслсй этих сборищ; в делах церковного управления, вообще, царила полная неурядица и противодействие законным властям. Преданные слуги Государя и неуклонные исполнители Его державной воли, к числу которых принадлежал и я, подвергали опасности нераз жизнь свог. Смело, без прсувеличения могу сказать, что везде, во всех званиях и должностях я твердо и открыто держал правительственное знамя, стойко преслсдовал одно истинное служение престолу и отечеству, о чем в свое время свидетельствовал пред Государем Императором граф Муравьев, а затем и его преемники. Результатом сего было то, что после неоднократных всемилостивсйших наград, мне пожалованных, я в 1866 году, облечеп высоким доверием в Бозе почившего Государя Императора Александра Николаевича, призвавшего мсня на должиость адмипистратора Виленской римско-католической епархией, а затем вскоре и Минской, по присоединепии ее с Вилепской. Этими двумя епархиями я управлял безпрерывно 15 лет, пока в управление ими не вступили новопосвященные епископы. То депежное содержание, какое присвоено лицу, состоящему во главе католической епархии, я не получал, так как оно отпускалось и высылалось удаленшо му от должности и водворенному в одной из восточных губерний Империи епископу Красинскому; мне же лично производилось из остатков содержания суфраганов по 200 руб. в год и то лишь после слияния Минской епархии с Виленской.

Теперь, когда я неожиданно для мсня, сведен с служебного поприща и остаюсь при одном лишь звании пастыря, но без паствы; так как фактически и настоятельство Остробрамского костела предоставлено другому, а я предоставлен на поругание врагам проводимой мною правительственной системы я вынужден обратиться с всеподашейшей просьбой к Вашему Императорскому Величсству о назначении мне за 45 летнгю службу приличествугщей моему бывшему положениго и сану

${ }^{30}$ РГИА, ф. 821, оп. 3, д. 971, k. 108-109 v. 
пенсии; которая улучшив мое материальное положение, с тем вместе улучшит и нравственное, ибо Всемилостивейшее назначение мне пенсии лишит, злые и лукавые уста, поводов пропагағдировать, что верная моя служба Престолу и России не только не вмснега мне в заслугу но даже послужила во врсд и к унижению.

Вашего Императорского Величества верноподданшый

[wlasnoręczny podpis] Прелат препозит

Петр Адальбертович Жилинский

С.Петербург, 8 января 1884 года

Местожительства временное: монастырь С. Екатерины

\section{EIN BEITRAG ZUR BIOGRAPHIE VON P. PIO'TR ŻYLIŃSKI}

\section{Zusammenfassung}

Die Geschichte des Bistums Wilna im 19. Jahrhundert widerspiegelt die schwierige Situation der katholischen Kirche im Russischen Reich. In der - nach der Verbannung von Adam Krasiński nach Wiatka (1863) - ihres Bischofs beraubten Diözese regierte für kurze Zeit P. Józef Bowkiewicz, der noch versuchte, eine gewisse Unabhängigkeit von den Zivilbehörden zu bewahren. Nach seinem Tode wurde auf Geheiß des Wilnaer Generalgouverneurs K. Kaufmann dann ein den zaristischen Behörden gegenüber viel loyaler eingestellter Nachfolger eingesetzt - P. Piotr Żyliński (1816-1887). Die beigefügten Archivdokumente stammen aus den im Staatlichen Russischen Historischen Archiv in Petersburg aufbewahrten Akten über P. Zyliński. Das erste Dokument betrifft den Akt der Wahl Żylińskis durch das Domkapitel zum Administrator der Diözese. Żylińskis Tätigkeit als Herrscher der Diözese Wilna und seit 1869 auch der Diözese Minsk charakterisiert die traurige Zeit des Übereinkommens mit der russischen Verwaltung. Wegen seiner unrechtmäßigen Herrschaft in der Diözese und der von ihm volizogenen Veränderungen in der Liturgie wurde der regierungstreue Administrator schließlich vom Heiligen Stuhl exkommuniziert. Während seines Urlaubs im Jahre 1882 hielt sich P. Żyliński in Rom auf, wo er eine Beichte ablegte. Nach der Zurïcknahme seiner Exkommunizierung schrieb er einen Brief an Prälat K. Linkin, der während seiner Abwesenheit die Diözese leitete. Darin verlieh der Verfasser seiner Reue und seinem Bedauern über seine falschen Entscheidungen Ausdruck (Dokument 2). Nach seiner Rückkehr nach Wilna übte er dann auch keinerlei administrative Funktionen mehr aus. Von den meisten Geistlichen und Gläubigen wurde er ignoriert, da es dem Heiligen Stuhl gelungen war, Bischof Karol Hryniewieciki in Wilna einzusetzen (1883). Ein Jahr darauf schrieb er einen Brief an den Zaren (Dokument 3), in dem er diesen um eine angemessene Rente für seinen 15-jährigen Dienst auf dem Posten des Administrator der Diözese bat, auf den er, wie er selbst unterstrich, ja von den Zivilbehörden berufen worden war. 